\title{
Prevalence of iodine deficiency disorders in the United Arab Emirates measured by raised TSH levels
}

H. Al-Hosani, ${ }^{1}$ H. Osman, ${ }^{2}$ L. Abdel Wareth, ${ }^{2}$ D. Saade ${ }^{\dagger}$ and M. Salah ${ }^{1}$

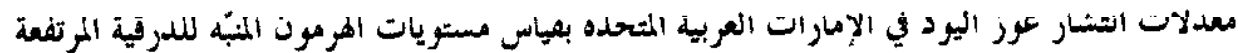

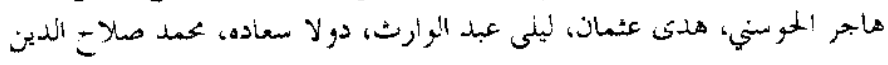

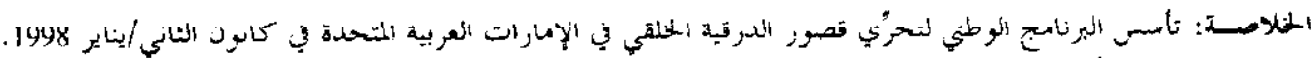

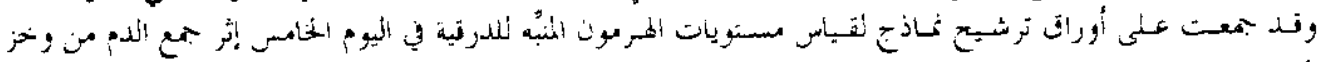

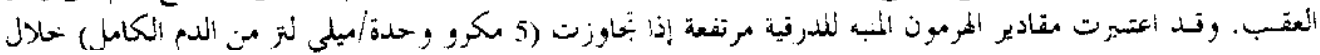

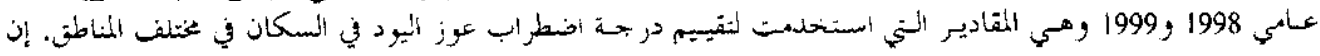

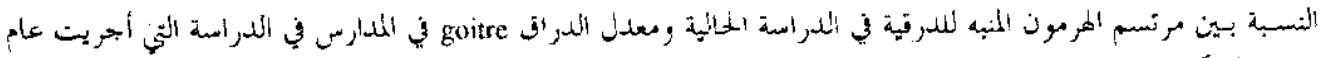

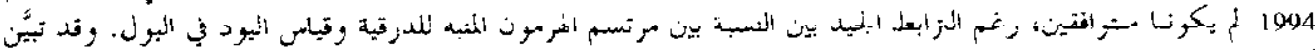

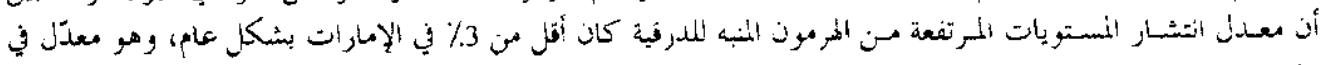

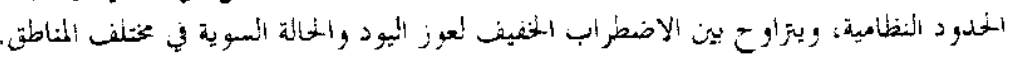

ABSTRACT The United Arab Emirates National Screening Programme for Congenital Hypothyroidism was established in January 1998. The programme measures nennatal thyroid-stimulating hormone (TSH) levels of blood samples collected on fitter paper on day 5 by heel prick. The prevalence of raised TSH levels (> $4 \mathrm{UU} /$ $\mathrm{mL}$ whole blood) during 1998 and 1999 was used to evaluate the degree of iodine-deficiency disorders (IDD) in the population in different regions. The ratio of TSH profile in the present study and goitre rate in schools in a 1994 study were discrepant, although there was good correlation between the ratio of TSH profile and urinary iodine. The prevalence of raised TSH leve's was $<3 \%$ in the Emirates overall, which is normal, and IDD varied from mild to normal problems in different regions.

Prévalence des troubles dus à une carence en lode aux Emirats arabes unis mesurée par l'élévation du taux de la TSH

RESUME Le programme national de dépistage de l'hyperthyroidie congénitale aux Emirats arabes unis a été créé en janvier 1998. On a déterminé le taux d'hormone thyréotrope (TSH) sérique dans des échantillons sanguins recueillis sur du papier filtre au cinquième jour de vie par prélèvement d'une goutte de sang au talon. La prevalence de l'èlevation du taux de I $\mathrm{SH}$ (> $5 \mu \mathrm{U} / \mathrm{mL}$ de sang total) en 1998 el 1999 a ele utlllsee pour évaluer le degré de troubles dus à une carence en iode (TCl) dans la population de différentes régions. Il y avait une divergence entre le profil de la TSH dans la présente étude et le taux de goitre dans les écoles dans une etude réalisée en 1994, mème s'il y avait une borno corrólation entro lo profil de la TSH et le doeage do l'iode urinaire. La prévalence de l'élévation du taux de TSH était inférieure à $3 \%$ aux Emirats globalement, ce qui est normal, et le probléme de TCl variait entre un TCI bénin et normal dans les différentes régions.

Central Department of Maternal and Child Health, Ministry of Health, Abu Dhabi, United Arab Emirates. ${ }^{2}$ National Neonatal Screening Programme Laboratories, Laboratory Department, Ministry of Health, Abu Dhabi, Unitod Arab Emirotos.

Received: 01/02/01; accepted: 02/06/02

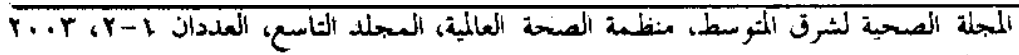




\section{Introduction}

lodine-deficiency disorders (IDD) result from insufficient iodine in the environment and inadequate intake of iodine from food. Because development of the central nervous system depends on an adequate supply of thyroid hormone, which requires iodine for biosynthesis, iodine is an essential micronutrient for normal intellectual development and function [1]. Communitybased assessments and iodine intervention trials indicate that IDD can leave entire populations with reduced intellectual capacity and impaired motor function. Mild iodine deficiency can reduce average population cognitive scores by $10 \%-15 \%[2]$.

In 1991, using the most current data, the world Health Organization (WHO) estimated that $20 \%$ of people throughout the world lived in areas in which iodine intake was inadequate. Subsequently, data became available that showed major cities in most of the developing world were also affected. In absolute terms, South-east Asia and the Western Pacific account for more than $50 \%$ of the total world population at risk. The Eastem Mediter rantan Region of WHO has the highest prevalence $(22.9 \%)$ of goitre in the world [3].

lodine deficiency is the world's single most significant cause of preventable brain damage and mental retardation [4]. Neonatal thyroid screening using serum thyroidstimulating hormone (TSH) as the primary screening test detects not only permanent sporadic congenital hypothyroidism, which has an incidence of approximately 1 per 4000 births, but also compensated or transient primary hypothyroidism, which can have an incidence as high as 1 in 10 neonates and the main cause of which is iodine deficiency [5].

Neonates exhibit elevated serum TSH more frequently than adults at a similar degree of iodine deficiency. Consequently. they appear hypersensitive to the effect of iodine deficiency. This characteristic can be explained by the particularly low iodine content of the thyroid of neonates and consequently by an accelerated turnover rate of their intrathyroidal iodine reserves [6].

The implementation of programmes of systematic screening for congenital hypothyroidism in neonates started in the early 1970s. These programmes allowed the early detection and therapy of infants affected by sporadic, permanent primary hypothyroidism and consequently prevented the development of severe mental retardation. They also allowed for the early detection of transient primary hypothyroidism, which is primarily caused by iodine deficiency and can result in impairment of intellectual capacity [5].

Neonatal serum TSH was included in 1994 by the WHO, the United Nations Children's Fund (UNICEF) and the International Council for Control of Iodine Deficiency Disorders (ICCIDD) as one of the indicators to assess iodine deficiency disorders and their control (Table 1) [3].

The assessment of the IDD status of a population is the basis for the development of a national IDD control programme [7]. There are three major components of data collection required for assessing and monitoring an iodine-deficient population. The first component is the determination of thyroid size and estimation of the prevalence of goitre. The problem of reproducibility of assessment by palpation, especially with the size estimation or smaller glands particularly in children, has led to the use of ultrasonography $[8,9]$. The second component, the determination of the urine jodine excretion, which is a direct measure of iodine intake, difficult to standardize $[10,11]$. The third and last component, the determination of TSH level, has significant limitations; for example, measurement of urinary iodine can be in the blood. TSH is a 


\begin{tabular}{|c|c|c|c|c|}
\hline \multirow[t]{2}{*}{ Indicator } & \multicolumn{4}{|c|}{ Severity of pubic health problem } \\
\hline & Normal & Mild & Moderate & Severe \\
\hline $\begin{array}{l}\text { Prevalence of goitre in } \\
\text { school-age children (\%) }\end{array}$ & $<5$ & $5-19.9$ & $20-29.9$ & $\geq 30$ \\
\hline $\begin{array}{l}\text { Prevalence of thyroid volume in } \\
\text { school-age children }>97 \text { th } \\
\text { percentile by ultrasound (\%) }\end{array}$ & $<5$ & $5-19.9$ & $20-29.9$ & $\geq 30$ \\
\hline $\begin{array}{l}\text { Median urinary iodine in school- } \\
\text { age children and adults (mg/L) }\end{array}$ & $100-200$ & $50-99$ & $20-49$ & $<20$ \\
\hline $\begin{array}{l}\text { Prevalence of neonatal } \\
\text { TSH }>5 \mathrm{mU} / \mathrm{mL} \text { whole blood }(\%)\end{array}$ & $<3$ & $3-19.9$ & $20-39$ & $\geq 40$ \\
\hline
\end{tabular}

promising indicator of iodine deficiency as it is easily measured with a highly sensitive and specific immunoassay using a small blood sample. The distribution of ISH values in a population can be used to detect even mild levels of iodine deficiency [0]. A shift in TSH levels during screenings towards higher values as well as a higher percentage of recalls were evident in the major cities of jodine deficient countries [12].

In 1994, a national IDD prevalence survey was conducted in the United Arab Emirates (UAE). Estimates were made of goitre prevalence in schoolchildren, urinary iodine excretion pattern in a subsample of the same children and iodine content in salt samples brought from home by the children [13]. Neonatal TSH screening was used as a monitoring tool to evaluate the degree of iodine deficiency and the results were compared with previous studies that used other indicators of iodine deficiency in the UAE.

\section{Methods}

The UAE consists of 7 Emirates, in geographic order from west to east: Abu Dhabi (which has three medical districts: Abu Dhabi, Al-Ain and the Western Region), Dubai, Sharjah, Ajman, Umm Al-Qaiwain, Ras Al-Khaimah and Fujairah.

The UAE National Screening Programme for Congenital Hypothyroidism was established in January 1998. It was based on the determination of neonatal TSH of blood samples collected on filter paper on day 5 by heel prick. TSH was assayed by Delfia fluorometric kits (Wallac, Finland).

We estimated the prevalence of raised TSH levels in different regions during 1998 and 1999 as an indicator of the degree of iodine deficiency in the UAE and compared it with other studies. The criterion for raised TSH was a level $>5 \mu \mathrm{U} / \mathrm{mL}$ whole blood. The IDD status of the different regions was classified according to the percentage of the population with raised TSH: $<3 \%$ normal; $3-19.9 \%$ mild IDD; $20-$ $39.9 \%$ moderate IDD; $>40 \%$ severe IDD [15].

The criterion for recalling the infants under suspicion of congenita! hyperthyroidism (CH) was defined as $\mathrm{TSH}$ level 
$>25 \mu \mathrm{U} / \mathrm{mL}$ whole blood. This criterion was applied to evaluate the degree of iodine deficiency in the different regions. If the proportion of babies with TSH $>25 \mu \mathrm{U} / \mathrm{mL}$ was $<0.1 \%$, the region was classified as normal (iodine replete); however, if it was $>0.1 \%$, the region was classified as iodine depleted.

The method used for statistical analysis was the chi-squared test for comparison between two percentages using SPSS software version 8 .

\section{Results}

The prevalence of TSH levels $>5 \mu \mathrm{U} / \mathrm{mL}$ whole blood in the different regions during 1998 and 1999 is given in Table 2. During 1998, only Al-Ain, Western Region, Ajman and Dubai were areas of mild IDD or above, i.e. they had TSH levels $>5 \mu \mathrm{U} / \mathrm{mL}$ in more than $3 \%$ of the population. All other regions were classed as normal, i.e. had raised TSH in less than $3 \%$ of the popula- tion. During 1999, mild IDD or above was evident only in the Western Region and Dubai. All other regions were normal. There was no significant difference in the prevalence of raised TSH between 1998 and 1999 for all regions except for $\mathrm{Abu}$ Dhabi, Al-Ain, Ajman and Sharjah where there was a significant decrease between 1998 and $1999(P<0.05)$. The prevalence of raised TSH in all UAE decreased from $2.6 \%$ in 1998 to $1.7 \%$ in 1999 (not statistically significant). In ench year, overall results for the UAE were within the normal range, i.e. $<3 \%$ of the population (Table 2 ).

The prevalence of raised TSH levels for the years 1998 and 1999 combined in the UAE overall was also normal ( $2.1 \%$ ). Mild IDD areas were Ajman and Dubai; all other regions were normal (Figure 1).

Table 3 gives the prevalence of TSH levels $>25 \mathrm{mU} / \mathrm{mL}$ in different regions. During 1998, only Umm Al-Qaiwain, Ajman, Ras Al-Khaimah and Al-Ain were iodine depletion areas, i.e. had TSH levels >

Table 2 Prevalence of neonatal thyroid-stimulating hormone (TSH) levels $>5 \mathrm{mU} / \mathrm{ml}$ at screening for congenital hypothroidism during Feb-Dec 1998 and Jan-Dec 1999

\begin{tabular}{|c|c|c|c|c|c|c|c|c|}
\hline \multirow[t]{2}{*}{ Emirate/district } & \multicolumn{4}{|c|}{1998} & \multicolumn{4}{|c|}{1999} \\
\hline & $\begin{array}{c}\text { No. of live } \\
\text { births }\end{array}$ & $\begin{array}{c}\text { No. cases } \\
\text { tested }\end{array}$ & $\begin{array}{c}\text { Raisec } \\
\text { No. }\end{array}$ & $\underset{\%}{\mathrm{TSH}}$ & $\begin{array}{l}\text { No. of live } \\
\text { births }\end{array}$ & $\begin{array}{c}\text { No. cases } \\
\text { tested }\end{array}$ & $\begin{array}{l}\text { Rais } \\
\text { No. }\end{array}$ & $\begin{array}{c}\text { TSH } \\
\%\end{array}$ \\
\hline \multicolumn{9}{|l|}{ Abu Dhabi } \\
\hline Abu Dhabi & 11281 & 8265 & 168 & 2.0 & 11914 & 10354 & 140 & 1.4 \\
\hline Al-Ain & 7500 & 4320 & 143 & 3.3 & 7800 & 5888 & 128 & 2.2 \\
\hline Western Region & 1028 & 736 & 25 & 3.4 & 1053 & 952 & 32 & 3.4 \\
\hline Ajman & 1688 & 1400 & 95 & 6.8 & 1897 & 1441 & 31 & 2.2 \\
\hline Dubai & 13962 & 709 & 24 & 3.4 & 12530 & 904 & 46 & 5.1 \\
\hline Fujairah & 1210 & 1099 & 16 & 1.5 & 2373 & 1358 & 20 & 1.5 \\
\hline Ras Al-Khaimah & 2559 & 1653 & 32 & 1.9 & 2788 & 1956 & 29 & 1.5 \\
\hline Sharjah & 5172 & 4526 & 82 & 1.8 & 5998 & 5006 & 37 & 0.7 \\
\hline Umm Al-Qaiwain & 644 & 408 & 5 & 1.2 & 721 & 510 & 8 & 1.6 \\
\hline Total & 45044 & 23116 & 590 & 2.6 & 47074 & 28369 & 471 & 1.7 \\
\hline
\end{tabular}




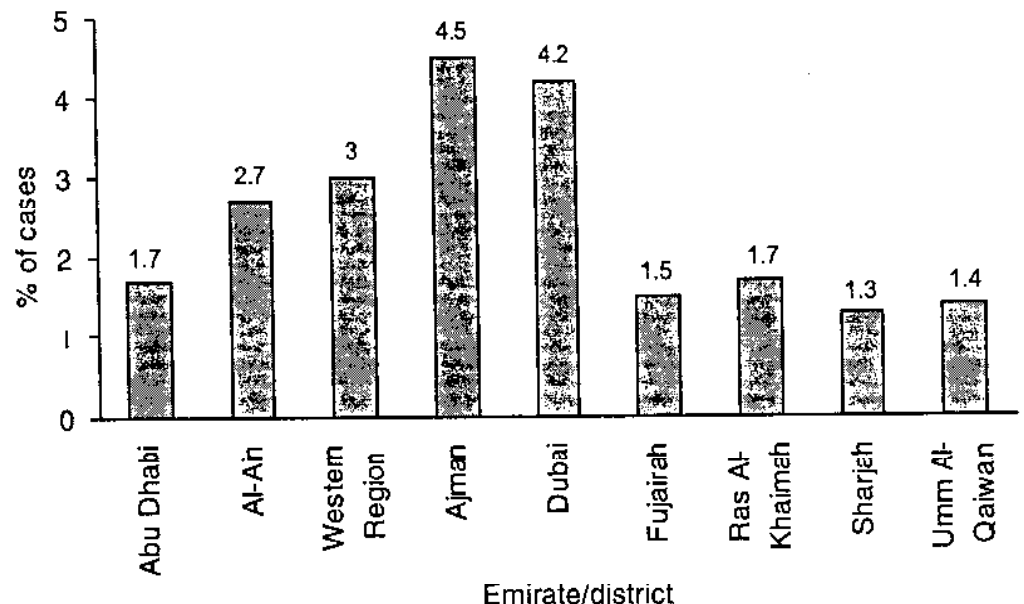

Figure 1 Prevalence of raised neonatal thyroid-stimulating hormone (TSH) levels $>5 \mathrm{mU} / \mathrm{mL}$ for 1990 and 1999 comblned

$25 \mathrm{mU} / \mathrm{mL}$ in more than $0.1 \%$ of the population. All other regions were classed as normal, i.e. prevalence of $\mathrm{TSH}>25 \mathrm{mU} /$ $\mathrm{mL}$ in less than $0.1 \%$ of the population.
During 1999, only Dubai, Ras Al-Khaimah, Sharjah and the Western Region were iodine depletion areas. All other regions were nomal. The prevalence of TSH $>25 \mathrm{mU} /$

\begin{tabular}{|c|c|c|c|c|c|c|}
\hline Emirate/district & & 1998 & & & & \\
\hline & tested & No. & $\%$ & tested & No. & $\%$ \\
\hline Abu Dhabi & & & & & & \\
\hline Abu Dhabi & 8265 & 4 & 0.05 & 10354 & 7 & 0.07 \\
\hline Al-Ain & 4320 & 5 & 0.12 & 6888 & 6 & 0.10 \\
\hline Western Region & 736 & 0 & 0.00 & 952 & 1 & 0.11 \\
\hline Ajman & 1400 & 2 & 0.14 & 1441 & 1 & 0.07 \\
\hline Dubai & 709 & 0 & 0.00 & 904 & 4 & 0.44 \\
\hline Fujairan & 1099 & 1 & 0.09 & 1358 & 1 & 0.07 \\
\hline Ras Al-Khaimah & 1653 & 2 & 0.12 & 1956 & 3 & 0.15 \\
\hline Sharjah & 4526 & 2 & 0.04 & 5006 & 7 & 0.14 \\
\hline Umm Al-Qaiwain & 408 & 1 & 0.25 & 510 & 0 & 0.00 \\
\hline Total & 23116 & 17 & 0.07 & 28369 & 30 & 0.11 \\
\hline
\end{tabular}


$\mathrm{mL}$ in all UAE increased from $0.07 \%$ in 1998 to $0.11 \%$ in 1999 (not statistically significant) (Table 3).

The value for the years 1998 and 1999 combined in the UAE overall was $0.09 \%$. Dubai, Ras Al-Khaimal, UnnI Al-Qaiwain, Ajman and Al-Ain were iodine depletion areas (Figure 2); all other areas were normal.

\section{Discussion}

The prevalence of raised TSH over the two-year period 1998-99 in all UAE was within the normal range $(<3 \%$ of the population) and the prevalence of TSH levels in the different regions varied between mild IDD problems (Amman and Dubai) and normal for all other regions.

A study conducted in 1994 that used other indicators of iodine deficiency in the UAE (Pandov CS, unpublished data) reported a goitre rate among schoolchildren $(40.4 \%)$ that indicated that the UAE had a severe IDD problem. The discrepancy between their reported goitre rate and the TSH profile of the present study may be due to high interobserver variation in the detection of goitre. There was a good correlation between the ratio of TSH profile of our study and measurement of urinary iodine that indicated that the UAE could be classified as a mild iodine-deficient region. The individual regions, however, could not be evaluated with confidence due to the small sample size of urinary iodine specimens in the 1994 study. Therefore, it cannot be compared with the ratio of TSH profile within the individual regions in the present study.

There was a significant decrease in the prevalence of TSH $>5 \mu \mathrm{U} / \mathrm{mL}$ between 1998 and 1999 for Abu Dhabi, A1-Ain, Sharjah and Ajman that could be explained by recent health awareness of the importance of salt iodization.

The prevalence of $\mathrm{TSH}>25 \mu \mathrm{U} / \mathrm{mL}$, i.e. the recall rate, for both 1998 and 1999 was $0.09 \%$ with a high recall rate, i.e. above $0.1 \%$, evident only in Dubai, Ras AlKhaimah, Umm Al-Qaiwain, Ajman and A1Ain. A 1986 study based on a survey of data from Europe indicated that the recall rate was below $0.1 \%$ in iodine repletion areas [13]. By comparison, the UAE in general is within the normal tange, i.e. no IDD, and its regions vary between iodine-depletion areas (Dubai, Ras Al-Khaimah, Umm AlQaiwain, Ajman and Al-Ain) and normal for all other regions.

People in some countries now have an iodine intake that is unnecessarily high and may occasionally be associated with io-

Table 4 Comparison of prevalence indicators of jodine-deficiency disorders (IDD) in the IInifed Arab Emiratos and sovority of tho publio health problem

\begin{tabular}{lcc}
\hline Indicator & $\begin{array}{c}\text { Value } \\
\text { Severity of public } \\
\text { health problem }\end{array}$ \\
\hline Prevalence of goitre in school-age children $(\%)^{\mathrm{a}}$ & 40.4 & Severe \\
Median urinary iodine in school-age children $(\mathrm{mg} / \mathrm{L})^{\mathrm{a}}$ & 90.5 & Mild \\
Prevalence of neonatal TSH $>5 \mathrm{mU} / \mathrm{mL}$ whole blood $(\%)$ & 2.1 & Normal \\
\hline 'Source [13]. & & \\
'ACcording to WHO, UN/CEF and ICCIDD recommendations [3]. \\
ISH = thyroid-stimulating hormone.
\end{tabular}




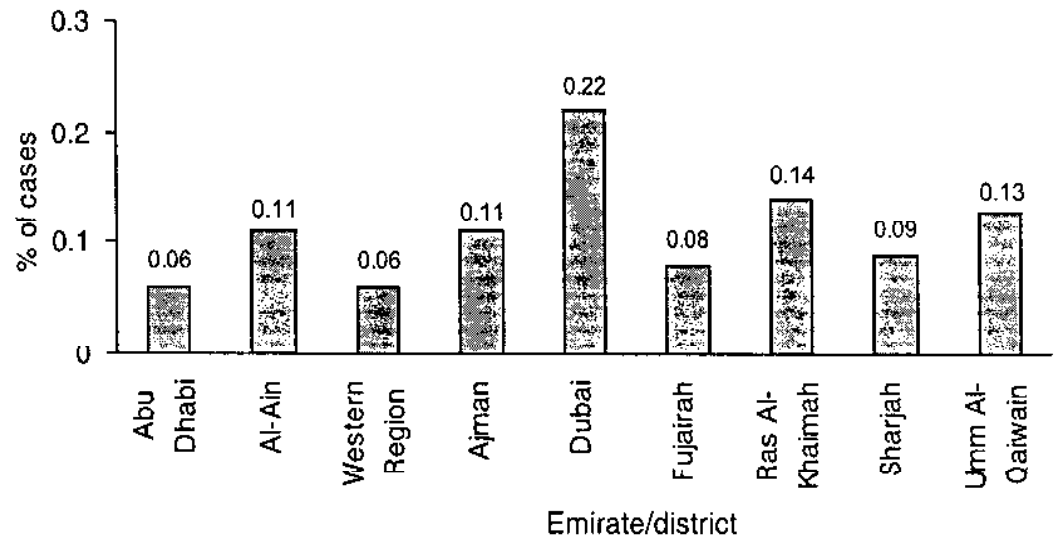

Figure 2 Prevalence of raised neonatal thyroid-stimulating hormone (TSH) levels $>25 \mathrm{mU} / \mathrm{mL}$ for 1998 and 1999 combined

dine-induced hyperthyruidism. This is probably related to the relative increase and the rapidity of increase of iodine intake that occurs when iodized salt is introduced in populations that are severely iodine deficient $[14]$. In the UAE however, there sloould be no risk of hyperthyroidism if a salt iodization programme is launched as iodine levels fall within the normal or mild IDD range.

\section{Conclusion}

This IDD prevalence survey shows that the UAE population overall is within the normal range. Different emirates/districts vary from a mild IDD problem to normal. Neo- natal TSH screening is a particularly sensitive monitoring tool for evaluating the effects and correcting iodine deficiency at the population level. Further studies are needed to describe the distribution of TSH values in the UAE population, especially for high-risk groups including pregnant women, school-age children and neonates.

\section{Acknowledgements}

We would like to thank members of the regional screening programme, laboratory staff and our colleagues in the MCH department, Dr T. Hashem, Mrs A. Ashkir, Mrs J. Farid and Mrs A. Abdulla, for their assistance.

\section{References}

1. Rernal J, Nunez J. Thyroid hormones and brain development. European journal of endocrinology, 1995, 133:390-8.

2. Calaciura $F$ et al. Childhood $I Q$ measurements in infants with transient congenital hypothyroidism. Clinical endocrinology. 1995, 43:473-7.

3. World Health Organization, United Nations Children's Fund, and the Interna-

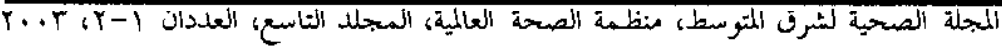


tional Council for Control of lodine Deficiency Disorders. Indicators for assessing iodine deficiency disorders and their control through salt iodization. Geneva, World Health Organization, 1995:1-55. (WHO/NUT/94.6.)

4. Delange $F$. The disorders induced by iodine deficiency. Thyroid, 1994, 4:107 28.

5. Carta Sorcini $M$ et al. Influence of environmental iodine deficiency on neonatal thyroid ecrooning rosulte. Journal of endocrinological investigation, 1988, 11: 309-12.

6. Delange F. Screening for congenltal hypothyroidism used as an indicator of the degree of iodine deficiency and of its control. Thyroid, 1908, 8:1185 02.

7. Delange F. Risks and benefits of iodine supplementation. Lancet, 1998, 351: 923.

8. Hetzel BS. lodine deficiency disorders (IDD) and their eradication. Lancet. $1983,2: 1126$.

9. Vitti $P$ et al. Thyroid volume measurement by ultrasound in children as a tool for the assessment of mild iodine deficiency. Journal of clinical endocrinology and metabolism, 1994, 79:600.

10. Gutekunst R, Delange F. Assessment techniques and the epidemiology of iodine deficiency disurders in Europe. European journal of internal medicine, 1992, 3(suppl. 1):71.

11. Bourdoux PP. Measurement of iodine in the assessment of iodine deficiency. IDD newsletter, 1988, 4:8.

12. Sullivan KM et al. Use of thyroid stimulating hormone testing in newborns to identify iodine deficiency. Journal of nutrition, 199\%, 12/:55.

13. Delange $F$ et al. Regional variations of iodine nutrition and thyroid function during the neonatal period in Europe. Biology of the neonate, 1986, 49:392-430.

14. Delange F. Bourdoux P. Frmans AM Neonatal thyroid screening used as an index of extraphysiological supply of iodine. In: Hall R, Kobberling $\mathrm{J}$, eds. Thyroid disorders associated with iodine deficiency and excess. New York, Raven Press, 1985:282-3. 